\title{
Die aktante-model van AJ Greimas
}

\author{
GMM Pelser
}

\section{INLEIDEND}

Soos dit ook geld ten opsigte van ander eksponente van een of ander vorm van "strukturalisme", het ook Greimas sy voorlopers gehad deur wie hy beinvloed is en wie se insigte hy kon gebruik en aanpas vir die konstruksie van sy eie model. Terwyl die ontstaan van strukturalisme in sy geheel metodologies gesproke teruggevoer word tot by die strukturele linguistiek van Ferdinand de Saussure, is daar in die geval van Greimas veral twee voorlopers wat vermelding verdien.

\subsection{Claude Lévi-Strauss}

Die antroploog Lévi-Strauss se analise van die mite by primitiewe volkere en die insigte wat hy daardeur bekom het, het 'n groot impak gehad op die bestudering van vertelstrukture, veral in Frankryk. Die invloed wat deur hom uitgeoefen is, het hoofsaaklik ' $n$ uitwerking gehad op dié een van die twee "skole" van Franse strukturaliste waartoe Greimas behoort. Veral twee van Lévi-Strauss se konsepte is deur Greimas as baie bruikbaar oorgeneem. Die eerste is Lévi-Strauss se siening in verband met die diep of latente strukture wat ten grondslag lê aan 'n vertelling en waaruit die vertelling se oppervlaktestruktuur gegenereer word. Hierdie struktuur is 'n konstante gegewenheid wat voorafgaan aan en dieper lê as die verteller se bewustelike manipulasie van die vertelling op die oppervlaktestruktuur. Anders as Lévi-Strauss, is Greimas egter nie slegs geïnteresseerd in die analise van hierdie dieptestruktuur nie, maar beweeg hy ook na die oppervlaktestruktuur van die vertelling. Die tweede belangrike konsep waarvan Lễvi-Strauss uitgegaan het en wat teruggaan op Roman Jakobson, is dié van binêre opposisie. Hiervolgens sien hy grondliggend aan die mite die generatiewe binêre "kodes" van sake of dinge wat in opposisie met mekaar staan, soos byvoorbeeld lewe/dood. Wat hiermee na vore gebring word, is dat dit eenvoudig 'n feit is dat elke mens die wêreld van dinge en verskynsels rondom hom in binêre teenoormekaarstaande relasies waarneem en ook sy denke so orden. Hierdie binêre opposisies is of word nie deur die mens geprojekteer nie maar is eenvoudig in die empiriese wêreld aanwesig. Al wat die mens in sy denke doen, is om hierdie opposisies te identifiseer en te orden, en in sy vertellinge oor hierdie wêreld tree hierdie opposisionele relasies dan ook aan die 
orde. Die motivering vir die mite is dan om hierdie teenoormekaarstaande pole met mekaar te versoen. Om die binêre relasie van betekenisse tot mekaar te bepaal, het Lévi-Strauss vervolgens die Aristoteliese logiese vierhoek geïmplementeer. Hiervan kon Greimas op sy beurt gebruik maak om die semantiese relasie tussen die verskillende "funksies" van die aktante-model te bepaal.

\subsection{Vladimir Propp}

Die grootste en belangrikste invloed op die werk van Greimas het egter uitgegaan van die Russiese folkloris Vladimir Propp, hoewel self nie 'n strukturalis nie. Propp het gestel dat elke objek vanuit drie gesigspunte ondersoek kan word, naamlik vanuit die struktuur, die oorsprong en die transformasies daarvan. Voordat 'n mens egter na die oorsprong van 'n ding kan vra, moet 'n mens weet wat daardie ding is. En om te weet wat dit is, moet jy dit kan beskryf. En wat beskryf moet word, is die struktuur van daardie objek. Propp het hom gevolglik daarop toegelê om die struktuur, die morfologie, van die volksverhaal te ondersoek en te beskryf. (Hy het vir dié doel honderd Russiese volksverhale, almal komedies, ondersoek.) Hy het van die vooronderstelling uitgegaan dat om die struktuur van ' $n$ verhaal te bepaal, daar vasgestel moet word wat die valensie van die verskillende handelinge/optredes in die vertelling tot mekaar is. Hy het naamlik vasgestel dat, terwyl die karakters of akteurs in die verhale wissel, hulle handelinge gereduseer kan word tot ' $n$ bepaalde aantal funksies wat by herhaling voorkom. Vir elke funksie is daar verskillende soorte handelinge wat daarmee korrespondeer, al sou sulke handelinge op die oppervlak verskillend lyk. 'n Funksie is dus ' $n$ generiese eenheid wat deur verskillende spesies van handeling gevul kan word. Die benaminge van die "dramatis personae" kan verander word, maar die funksies wat deur hulle handelinge vervul word, nie. Die struktuur van 'n vertelling moet derhalwe in die lig van hierdie funksies beoordeel en geanaliseer word. En die funksies word beoordeel in terme van die bydrae wat hulle mak tot die ontvouing van die "plot" van die vertelling.

Met die oog op ons studie is die belangrikste teses wat deur Propp neergelê is, die volgende:

(i) Die funksies dien as stabiele, konstante elemente van die vertelling en konstitueer daarom die fundamentele komponente daarvan.

(ii) Dit is beperk tot 31

(iii) Dit kom altyd in dieselfde volgorde (sintagmatiese suksessie) in die vertelling voor.

Propp het verder vasgestel dat 'n vertelling saamgestel is uit verskil- 
lende episodes of bewegings waarvan die belangrikste is die funksies wat aan die begin en die einde van die vertelling voorkom, met een of meer episodes wat daar tussenin afspeel. ' $n$ Komedie begin gewoonlik met 'n daad van boewery waardeur 'n gebrek ("lack") ontstaan (of dit begin met die gebrek self) en eindig met die herstel van die oorspronklike situasie, dit wil sê die uitskakeling van die gebrek ("lack liquidated"). Tussen hierdie twee episodes vind dan die gebeure (funksies) plaas wat die uitskakeling of beëindiging van die gebrek bewerkstellig.

Ons het in bogenoemde geval natuurlik met die tipies komiese plotontwikkeling te doen, soos Propp dit aangetref het by al die volksverhale wat hy ondersoek het. Die plotontwikkeling vertoon dus ' $n$ ommekeer van die vroeëre situasie; begin en einde staan in omgekeerde relasie tot mekaar. Dieselfde patroon van plotontwikkeling kom natuurlik ook by die tragedie voor. Hier begin die verhaal natuurlik met 'n gunstige situasie en eindig met ' $n$ tragiese.

Dit kan grafies soos volg voorgestel word:

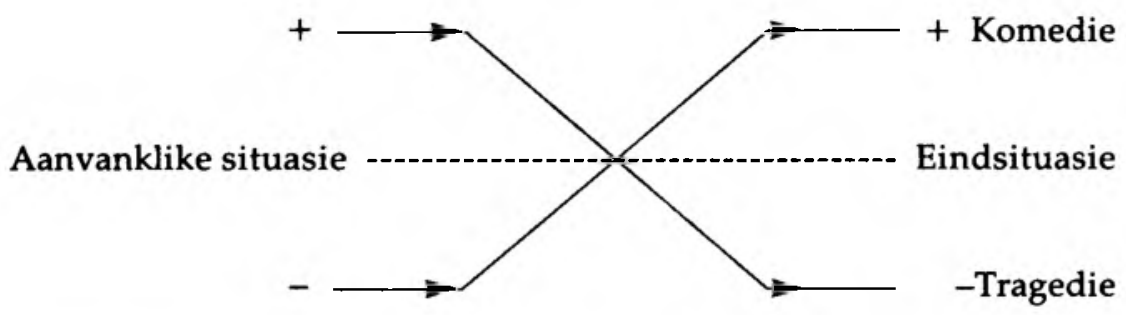

Hoewel die funksies onafhanklik van die akteurs, wat veranderlikes is, gedefinieer word, blyk dit dat die akteurs volgens ' $n$ bepaalde orde onder hulle verdeel word. Die funksies groepeer dus saam in sekere logiese handelingsfere waarmee sekere akteurs geassosieer word. ' $n$ Bepaalde akteur sal dus altyd 'n bepaalde handeling of funksie vervul, dit wil sê die boef in die verhaal kan nie tegelyk die held in die verhaal wees nie, behalwe as daar in die verhaal 'n mikro-vertelling geskep word waarin hy as held optree, maar dan kan hy weer nie daarin tegelyk die boef wees nie. Die volgende groeperinge van sfere van handeling word deur Propp onderskei:

(i) Die boef/opponent/antagonis - pleeg boewery, veg teen die held, agtervolging.

(ii) Die gewer ("donor") - verskaf towerkrag of besondere vermoë aan die held.

(iii) Die helper - help die held na die bestemde plek, skakel uit wat ontbreek, red van agtervolging, los moeilike take op, help die held om van gedaante te verander.

(iv) Die begeerde persoon/saak, ("sought-for-person", prinses) en 
haar vader - moeilike take opgelê, brandmerking, blootstelling, herkenning, straf van tweede boef, huwelik.

(v) Die sender - stuur die held.

(vi) Die held/protagonis - vertrek op soektog, reaksie op eise van gewer, huwelik.

(vii) Die vals-held - vertrek op soektog, reaksie op eise van gewer, eis dinge op as vals-held.

Hiervolgens is ' $n$ volksverhaal 'n vertelling met 7 karakters wat die funksies deel. Ons moet daarom wanneer ons die dieptestruktuur analiseer, nie let op die karakter van die akteurs soos dit op die oppervlaktestruktuur ("performance text") gemanifesteer word nie, maar op hulle sfeer van handeling. Ons moet dus die akteurs beskou as verskillende realiserings van die veranderlike aktante (kyk later) op die oppervlaktestruktuur. Propp het hierby vasgestel dat daar drie logiese moontlikhede is vir die verhouding tussen akteurs en die sfere van handeling, naamlik dat:

- een karakter verskillende handelingsfere kan vul;

- 'n handelingsfeer tot slegs een karakter beperk kan wees;

- 'n enkele handelingsfeer verdeel kan wees onder verskillende karakters.

\section{DIE MODEL VAN GREIMAS}

\subsection{Die strukture van ' $n$ vertelling}

Soos reeds aangedui, het Greimas wat sy beskouing oor die strukture van ' $n$ vertelling betref, gedeeltelik van die konsep van LéviStrauss gebruik gemaak maar ook verder as Lévi-Strauss gegaan. Greimas onderskei naamlik drie strukture eie aan 'n vertelling:

(i) Eerstens is daar die dieptestruktuur(e). Dit is die strukture wat inherent is aan elke menslike gemeenskap en die wyses van bestaan van die gemeenskap. Dit is die wyses waarvolgens die gemeenskap sy wereld orden. Dit is dus 'n strukturele gegewenheid in elke gemeenskap en dit is oral dieselfde, ongeag in watter taal dit tot uitdrukking gebring word. Dit is op hierdie vlak dat daar die logiese verbande tussen dinge en sake aangetref word soos opposisie, implikasie ensovoorts. Dit lê in die diepte ten grondslag aan alle vertellinge.

(ii) Tweedens is daar die kunsmatige ("superficial") struktuur. (Kunsmatig nie in pejoratiewe sin nie, maar om aan te dui dat dit nader aan die manifestasievlak geleë is as aan eersgenoemde vlak.) Hierdie struktuur is nie logies nie maar antropomorf, want dit is op hierdie vlak dat die aksie wat in die dieptestruktuur 
deur die binêre opposisies geïmpliseer is, tot verwerkliking kom. Kwalifikasies van die dieptestruktuur word hier tot funksies. (Waar ons byvoorbeeld in die dieptestruktuur "dood" het as 'n logiese negasie van "lewe", sal dit op die "kunsmatige" vlak tot ' $n$ aksie van die bedreiging of vernietiging van lewe word.) Hierdie vlak is ook die vertel-grammatika van die vertelling. Dit is onderliggend aan die manifestasievlak van die vertelling, en word ook genoem die vertellingsoppervlakte-struktuur. Die oppervlaktestruktuur word uit hierdie "kunsmatige" struktuur gegenereer.

(iii) Derdens is daar die manifestasiestruktuur of -vlak. Dit is die struktuur van die vertelling soos dit linguisties heel op die oppervlakte van die teks manifesteer.

Hierdie vlakke kan grafies soos volg voorgestel word:

Linguistiese oppervlaktestruktuur

Vertelling Manifestasievlak

Linguistiese dieptestruktuur

Vertellingsoppervlaktestruktuur ("superficial level")

Plot

Vertellingsdieptestruktuur

Anders as die semantiese struktuuranalise wat op die basis van die Transformasionele Generatiewe Grammatika die betekenis van 'n teks op die linguistiese dieptestruktuur deur middel van transformasie vanuit die linguistiese oppervlaktestruktuur probeer vind, is Greimas nie primêr in hierdie manifestasievlak geïnteresseerd nie. Hy hou hom besig met die vertellingsoppervlaktestruktuur soos dit vanuit die dieptestruktuur gegenereer is. Hy vra dus na die verskillende funksies wat op hierdie vlak gemanifesteer word deur middel van die handelinge van die verskillende karakters in die vertelling. Dit is deur die onderlinge relasies tussen die karakters en hulle handelinge dat die intrige in die vertelling gekonstitueer word en die plot van die verhaal ontvou. "Such an analysis begins with a text which may be readable and yet hides the rules of its game. It ends when a system or an immanent structure is brought to light. Because it is immanent, such a structure is 'distant' from the 'surface' of the text... The structural description implies the passing over from concrete statements, as manifested in the text in a specific language and style, to abstract units capable of being elements of a 'system'. Such a system finds its coherence in an interplay of relations defined without reference to any concrete realization ... By contrast, the 
operations of analysis are aimed, so to speak, at textual 'models' kept in a 'locus' far removed from the texts. In this locus everything is rigorously logical. Nothing escapes from the network of relations. It is from this remote locus that texts spring forth" (Calloud 1976: 3).

Dit is uit hierdie opmerking van Calloud duidelik watter klem daar gelê word op die relasionele karakter van die struktuur van 'n vertelling. Daarom dat hy ook sê: "Everything must be defined in terms of relation" (Calloud 1976: 7). Hierdie relasie word in en deur die manifestasie van die teks verberg. Hoe meer 'n mens slegs by die oppervlakte van die teks bly, hoe meer kom dit voor asof die eenhede op die oppervlak betekenis in hulleself het. Hoe meer ons egter die teks benader in terme van die struktuur daarvan, hoe meer word die eenhede opgebreek en vertoon hulle hulle relasionele status en hulle deelname aan 'n eindelose netwerk van korrelasies ... "in which everything is difference" (Calloud 1976: 8).

\subsection{Die "lexie"}

Die strukturalis begin sy strukturele analise van 'n vertelling deur die teks in lexies op te deel. Die lexie is 'n leeseenheid en behoort daarom slegs tot die leesvlak, dit wil sê dit is 'n eenheid wat nie tot die sisteem behoort nie. Dit kan bestaan uit verskillende sinne, uit slegs een sin of uit slegs 'n gedeelte van' $n$ sin. Die minste wat van 'n "lexie" gesê kan word, is dat dit 'n eenheid moet wees waarin daar iets gebeur ('n "happening"). 'n Lexie moet egter nie so afgebaken word dat daarin te veel gebeure plaasvind nie, want dan sal die interpretasie daarvan te ingewikkeld wees. Elke gebeure is die tot stand bring van ' $n$ relasie. Iets gebeur byvoorbeeld wanneer een akteur in ' $n$ relasie tot ' $n$ ander gestel word. Die analitikus moet uit hierdie "lexie" vasstel wat die diepte-orde van die sin is en sodoende die relasie bepaal tussen die twee akteurs wat ter sprake is. In 'n sin soos: "Piet slaan vir Jan", word die sin dus nie so geanaliseer dat Piet as die subjek van die handeling beskryf word en Jan as die objek nie. Albei figureer hier as subjekte wat in resiproke relasie tot mekaar optree. Wanneer die sinne of "lexies" so geanaliseer word, word dit duidelik dat die teks soos 'n groot stuk materiaal is waarin verskillende soorte drade geweef is, naamlik akteurs, prosesse en kwalifikasies. Die "lexies" kan ook verdeel word in twee kategorieë, naamlik funksie en kwalifikasie (wat korrespondeer met die klassieke onderskeid tussen vertelling en beskrywing). Klem moet egter daarop gelê word dat die "lexie" gekonstitueer word deur akteurs en prosesse. In die voorbeeld hierbo gebruik, is "slaan" die proses wat deur die akteur Piet uitgevoer word. 


\subsection{Kanoniese vertelstellings ("canonic narrative statements")}

Vanaf die "lexie" beweeg die analise na die identifisering van die kanoniese vertelstellings wat daar in die teks opgesluit lê. Hierdie stellings behoort tot die vertelgrammatika ("narrative grammar") van die teks en hulle word so genoem om hulle te onderskei van linguistiese stellings op die oppervlakte van die teks. Hulle word deur middel van abstrakte en algemene kenmerke gedefinieer. Hulle konstitueer die minimale raamwerk waarbinne die basiese elemente van die vertelgrammatika gemanifesteer en in relasie tot mekaar gebring kan word. In so 'n stelling moet daar 'n kombinasie wees van minstens twee van die elemente van die vertelgrammatika, byvoorbeeld aktante en funksies. Elke kanoniese stelling kan die model en genereerder wees van verskillende linguistiese stellings. Hierdie stellings het ook ' $n$ vaste vorm wat bepaal word deur spesifieke soorte relasies wat onafhanklik is van die veranderlikes waardeur dit op die linguistiese oppervlaktestruktuur gemanifesteer word. Die relasies wat in die kanoniese stelling tot uitdrukking kom, is onveranderlikes. Op die linguistiese vlak, dit wil sê in die "lexies", word hulle deur variante op die oppervlak van die teks gemanifesteer. Om nie eentonig te wees nie, word daar op die oppervlakte van die teks gebruik gemaak van variasie van stylelemente, werkwoorde ensovoorts. Hierdie elemente van die teks is in 'n sekere sin ' $n$ struikelblok vir die analitikus om tot die kanoniese stellings en die relasie deur te dring. Verskillende werkwoorde gee dikwels uitdrukking aan dieselfde funksies in die vertelling. So skep die werkwoorde dikwels ' $n$ baie heterogene indruk. Die akteurs is egter meer stabiel omdat hulle vanweë hulle name of benaminge meer onderskeibaar is.

Die taak van die analitikus is om hierdie groot aantal veranderlikes tot 'n paar onveranderlikes te reduseer. Hy doen dit deur die prosesse wat in die teks plaasvind, te klassifiseer. Prosesse of werkwoorde kan in twee hoofklasse geklassifiseer word, naamlik dié van "doen" = die funksies, en dié van "toestand" ("being") = kwalifikasies. Hierdie klassifikasie kan nog verder verfyn word, sodat ons die volgende onderskeidinge kan aantoon:

(i) Die stellings wat uitdrukking gee aan die prosesse van doen, klassifiseer in vier subklasse, te wete -

- die somatiese: eet, beweeg, doodmaak, ensovoorts;

- die kommunikatiewe: bekendmaking van feite, gebeure, ensovoorts;

- die interpretatiewe: rekonstruering van gebeure op grond van bepaalde inligting;

- oorreding: van iemand om iets te onderneem.

(ii) Dié wat betrekking het op toestand ("having", "being", "quali- 
fication"), ook genoem predikatiewe stellings: byvoorbeeld hy is ryk, siek, ensovoorts.

(iii) Dié wat betrekking het op modaliteit: in drieërlei sin, naamlik om te wil, te ken, in staat te wees.

\subsection{Klassifikasie van funksies}

Om die strukturele analise verder te voer, is dit nodig dat die analitikus kennis neem van die wyse waarop die funksies van die vertelling geklassifiseer word en in watter relasie hulle tot mekaar staan. Soos ons reeds gesien het, is die funksies as abstrakte entiteite verfynde wetenskaplike konstruksies wat spesifiek ontwerp is vir die strukturele analise van vertellings. In die terme van Chomsky kan hulle gesien word as elemente van die kompetensie ("competence") van die vertelling in onderskeid met hulle "realiserings" op die teksoppervlakte as verskynsels van ("performance"). In die lig van die feit dat daar so ' $n$ verskeidenheid van realiserings van die funksies is, is dit soms moeilik om eenstemmigheid te bereik oor watter funksies daar in 'n spesifieke teks aanwesig is. Hierdie probleem is veral ook daaraan toe te skryf dat verskillende funksies op dieselfde "wyses" vervul kan word of dat identiese funksies op totaal verskillende wyses "gerealiseer" kan word. Daar is verder assimilasie van funksies deurdat ' $n$ aantal verskillende funksies met mekaar saamsmelt. Dit gebeur ook dat funksies morfologies dubbele betekenis kry deurdat 'n enkele realisering verskeie funksies tegelykertyd "realiseer" (kyk Güttgemanns 1976: 38).

In die lig van hierdie probleme in verband met die identifisering en definiëring van die (tipe) funksies, kan die vraag gevra word of dit dan nie uiteindelik as ' $n$ arbitrêre onderneming beskou moet word nie. Watter kriterium is daar dus waarvolgens op gekontroleerde wyse te werk gegaan kan word? Propp het in hierdie verband egter gestel dat dit altyd moontlik is om die funksies te definieer as daar gevra word na die uitwerking of konsekwensie van so 'n funksie. Ons moet dus as 't ware van die einde af terugwaarts werk om die aard van die funksies vas te stel. Die mees kontroleerbare instrument om die funksies mee te klassifiseer en te definieer bly egter die semiotiese vierhoek of seshoek wat gebaseer is op Aristoteles se logiese vierhoek. Vir die strukturalis is struktuur die semiotiese vierhoek van binêre opposisie. Dit word ook deur Greimas ' $n$ taksonomiese model genoem waarin 'n stel waardes van 'n semantiese mikro-wêreld in hulle binêre relasies georden word.

Basies kom die gebruik van die semiotiese vierhoek daarop neer dat met behulp daarvan vasgestel word watter funksies teenoorstaande ("contrary") met mekaar is, watter teenstrydig (ontken- 
nend, "contradictory") met mekaar is en watter van mekaar afgelei kan word.

Indien daar byvoorbeeld twee teenstrydige funksies tegelykertyd in ' $n$ vertelling aanwesig is, kan dit nie ' $n$ vertelling wees nie. So kan 'n held nie tegelykertyd op 'n sending vertrek èn aankom na voltooiing daarvan nie. Die vierhoek help ' $n$ mens verder om byvoorbeeld te weet dat as een funksie aanwesig is, die ander geïmpliseer word. As die held met die prinses trou, kan ons die afleiding maak dat hy die boef of opponent oorwin het.

Die vierhoek kan soos volg grafies geillustreer word in kombinasie met die klassieke voorbeeld wat deur Boethuis oorgelewer is:

gebrek (alle mense is regverdig)

gebrek

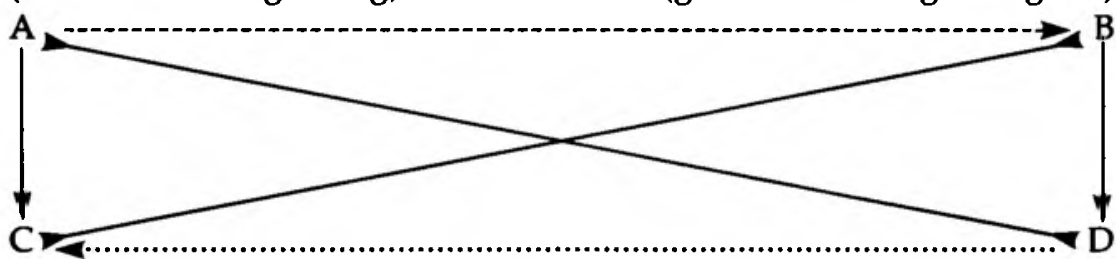

(party mense is regverdig)

(party mense is nie regverdig nie)

gebrek herstel

gebrek herstel

(Die streep bokant "gebrek" by B en "gebrek herstel" by C $=$ niegebrek, nie gebrek herstel.)

Tussen A en B is daar die teenoorgestelde "(contrary") opposisie, dit wil sê A en B kan nie tegelyk "waar" wees nie, maar albei kan tegelyk "onwaar" wees.

Tussen $A$ en $D$, en tussen $B$ en $C$ is daar ' $n$ teenstrydige opposisie, dit wil sê A (of B) en D (of C) kan nie tegelyk "waar" of "onwaar" wees nie. Slegs een van die twee kan te enigertyd "waar" of "onwaar" wees.

Tussen C en D is daar 'n sub-teenoorstaande ("subcontrary") opposisie, dit wil sê òf albei kan "waar" wees òf een van hulle is "onwaar", maar albei kan nie tegelyk "onwaar" wees nie.

Tussen A en C of tussen B en D is daar 'n verhouding van subordinasie of implikasie, dit wil sê albei kan tegelyk ò "waar" òf "onwaar" wees. Die eerste kan ook "onwaar" wees en die tweede "waar" of albei kan "onwaar" wees, maar die eerste kan nie "waar" wees en die tweede "onwaar" nie.

Teenoorstaande opposisie staan ook bekend as uitsluiting ("exclusion") en dié van teenstrydigheid as kontravalensie ("contravalence"). Subteenoorstaande opposisie word ook genoem skeiding (disjunksie, "disjunction") en dié van subordinasie, implikasie. 
R Blanché (1966: 44) het die vierhoek uitgebrei na 'n seshoek om sodoende voorsiening te maak vir tussenmoontlikhede. Ons kan dus aan die een kant 'n saamgestelde rolvervulling hê deurdat een aktant twee verskillende funksies kan uitoefen, byvoorbeeld helper èn opponent. Of ons kan 'n situasie hê waarin 'n aktant nòg helper nòg opponent is. Die aktantmodel van helper-opponent sal volgens die seshoekskema dan soos volg daar uitsien:

\section{Helper èn Opponent}

Helper

Nie-Helper

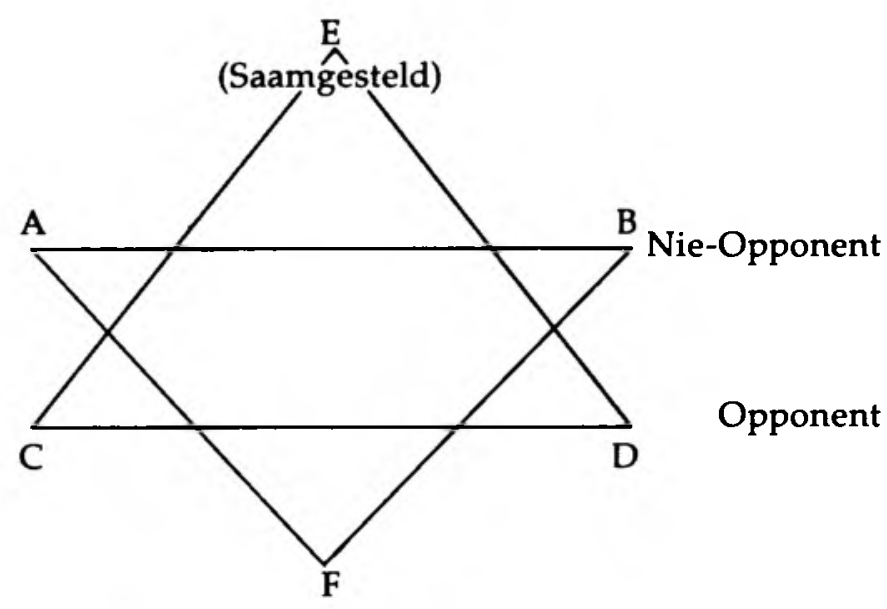

Nòg Helper - Nòg Opponent

(Neutraal)

Ons kan dit uit die gelykenis van die barmhartige Samaritaan prakties illustreer. Die priester en die Leviet is nòg helpers nòg opponente (posisie F: neutraal), terwyl die wetgeleerde (Lk 10:25) in 'n sekere sin helper èn opponent is (vgl. Galland 1976: 26).

Vir ons doel is dit egter nie nodig om verder op hierdie en ander verfynings van die logiese vierhoek in te gaan nie.

Greimas het die 31 funksies van Propp nog verder gereduseer tot 20, hulle volgens die logies-binêre prinsipes geherorganiseer en hulle uiteindelik in 7 pare georden. Dit beteken dat alle funksies wat daar in die vertelling plaasvind, onder minstens een van hierdie pare tuisgebring sal kan word. Hy het die pare soos volg onderskei en soos duidelik blyk, definieer elke paar mekaar wedersyds:

(i) Aankoms vs vertrek (en omgekeerd).

(ii) Vereniging vs skeiding ("conjunction vs disjunction").

(iii) Mandatering vs aanvaarding van mandaat.

(iv) Konfrontasie vs (nie binêr, moontlik assosiasie). 
(v) Dominasie vs onderwerping (oorwinning vs neerlaag as eindproduk van konfrontasie).

(vi) Kommunikasie vs ontvangs ("reception").

(vii) Bekroning vs ontneming ("attribution vs deprivation").

\subsection{Die aktante-model}

Soos die prosesse wat hulle in ' $n$ vertelling afspeel, gereduseer kan word tot funksies en kwalifikasies, so kan die akteurs gereduseer word tot aktant-rolle. Hierdie rolle is onveranderlikes wat, soos reeds by Propp hierbo aangedui, die verskillende handelingsfere beliggaam, en dit word verteenwoordig deur funksie \& aktant. Die term "akteur" is in die strukturalisme doelbewus vervang met die term "aktant". Hiervoor is daar meer as een rede. In die eerste plek dink 'n mens gewoonlik by die aanhoor van die term akteur aan lewende persone. Akteurs in 'n vertelling kan egter 'n bykans onbeperkte verskeidenheid van lewende wesens, dinge in die natuur, denkrigtings en selfs iets soos die geskiedenis insluit. Strukturalisme wil nie alleen dat die analitikus hiervan bewus moet wees nie, maar verkies ook aktant bo akteur, omdat die term aktant verwys na 'n onveranderlike abstrakte element in die strukturele patroon van interrelasies. Akteurs kom op die oppervlakte van die teks voor, terwyl die rol of funksie van die aktant op die vlak van die vertelling lê. Waarom dit nodig is om na die aktant te vra, eerder as die akteur, word gou duidelik as ons daarop let dat verskillende akteurs op die oppervlak van die teks die rol van één aktant kan vervul en dat omgekeerd één akteur verskillende aktant-rolle kan vervul (kyk Grosse 1977: 30).

Terwyl daar by Propp nog 7 handelingsfere voorgekom het, het Greimas hierdie sfere of rolle tot ses gereduseer en die model ietwat gewysig. Hy het naamlik die rolle van gewer \& helper en boef \& vals-held onderskeidelik saamgevoeg in helper en opponent en die rol van ontvanger tot die model toegevoeg. Sy model sien dan soos volg daaruit:

Sender

Objek

(begeerde saak of persoon)

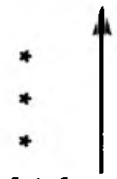

Helper Subjek (gewer \& helper) (held)

Opponent $++++++++++++++++++++++++++++++++++++t$ 
Die funksie van hierdie model is om die valensie van elke aktant se funksie in die geheel van die struktuur te bepaal. Die pyle dui daarom die gerigtheid van elke funksie aan. Hieruit word duidelik dat dit nie die aktant is wat van (primêre) belang is nie, maar die rol wat hy speel. Die aktant is slegs 'n rolvuller.

In die model figureer daar verder drie asse ("axes") waarlangs die gebeure van die vertelling afspeel.

- Die as van sender-objek-ontvanger (gemerk -..--.--) is die as van kommunikasie. Die sender wil (deur die mandaat wat hy aan die subjek gee) die objek aan die ontvanger kommunikeer.

- Die as van subjek-objek (gemerk *) is die as van wilsuiting ("volition") of wilsdaad. Die subjek wil die objek in besit kry (as van plot). Hierdie as kan egter alleen gerealiseer word as bepaalde struikelblokke uit die weg geruim word en daarom die noodsaak vir die derde as.

- Die as van helper-subjek-opponent (gemerk ++++++ ) is die as van mag (-uitoefening). Die subjek word in sy poging om die objek te bekom, teengestaan deur die opponent, en vir die stryd wat hy moet aanknoop, het hy die hulp van die helper nodig. Dit is op hierdie as dat die werklike aksie in die vertelling plaasvind.

As verdere illustrasie kan hierdie model op die gelykenis van die barmhartige Samaritaan toegepas word en sal die onderskeie rolle soos volg deur die aktante gevul word:

Sender

?

Helper

(kundigheid, olie, wyn,

donkie, geld, herber-

gier)
Objek

(gesondheid)

Subjek

(Samaritaan)
Ontvanger

(gewonde man)

Opponent

(rowers en effek van hulle optrede).

\subsection{Die sintagma}

Die vertelstellings wat in 'n vertelling voorkom, het die kenmerk dat hulle 'n string vorm. Hulle word dus nie lukraak georden of volgens die voorkeur van die verteller nie, maar op die basis van voorafbepaalde relasies, dit wil sê op die basis van 'n sintagma of 'n spesifieke kombinasiereël. Hieruit volg dat ook die funksies in die vertelling volgens 'n voorafbepaalde orde op mekaar volg, soos woorde in 'n sin. So 'n ordening of opeenvolging van funksies word 'n sintagma genoem. Die sintagmas is ook kanonies van aard, aangesien hulle gedefinieer word in terme van die sisteem en nie in terme van die 
vlak van realisering ("performance") nie. Die relasies waaruit hulle gekonstitueer word, bly konstant onder die manifestasievlak. Die volgende stap nadat die vertelstellings geïdentifiseer is, is om die verskillende sintagmas te identifiseer. Indien die vertelstellings reg geïdentifiseer is, is die ondersoek na die sintagmas betreklik maklik.

Tot dusver word daar in hierdie strukturele benadering drie tipes vertelsintagmas onderskei.

(i) Die kontraktuele ("contractual") sintagmas. Hulle bestaan uit twee funksies wat tegelyk suksessief en simmetries is, naamlik mandatering en aanvaarding. Albei hoef egter nie eksplisiet op die manifestasievlak voor te kom nie, een van hulle kan implisiet aanwesig wees. Hulle verteenwoordig die beginfase van die vertelling: 'n aktant word deur iemand versoek, gedwing of in staat gestel om 'n taak uit te voer. Die kontrak is 'n essensiële element van ' $n$ vertelling en dit word veronderstel by enige onderneming wat aangepak word, al word dit nie eksplisiet tot uitdrukking gebring nie. Dit hoef ook nie slegs by die begin van die vertelling voor te kom nie, dit sal ook binne die vertelling voorkom telkens wanneer iemand aan iemand anders 'n mandaat gee om iets te doen. Hierdie sintagma kan natuurlik ook 'n negatiewe vorm aanneem as die kontrak verbreek word of nie werklik tot stand kom nie.

(ii) Die skeidingsintagmas ("disjunctional"). Ook hierdie sintagmas bestaan uit twee suksessiewe funksies, naamlik aankoms en vertrek en terugkeer. Hulle kan maklik geïdentifiseer word en is minder bepalend vir die struktuur van die vertelling. Hulle dra egter by om te bepaal wat die aktante se bewegings is en hoe hulle ander aktante ontmoet. Vir sover die aktante oor die topografie van die vertelde wêreld beweeg, en in sekere vertellings is dit belangrik, dra hierdie sintagmas daartoe by om die teenwoordigheid van aktante by ander te beskryf en om die funksionele perke aan hulle te stel, wat weer daartoe bydra om hulle identiteit te bepaal. Ons kan in 'n sekere sin ook sê dat hierdie funksies die "locus" van die vertelling definieer.

(iii) Die performatiewe ("performancial") sintagmas. Hierdie sintagmas het te doen met die middeldeel van die vertelling, dit wil sê die deel waar die aksie plaasvind wat die gelukkige einde van die verhaal ten gevolg moet hê. Hierdie sintagmas is weer saamgestel uit drie stellings, naamlik:

- konfrontasie: wanneer die subjek (held) en die opponent (boef) met mekaar gekonfronteer word vir die stryd wat voorlê en waartydens die held ook van die helper die nodige hulp vir die stryd ontvang; 
- dominasie: een van die twee oorwin, en indien dit die subjek is, verseker hy ook daardeur dat die objek bekom kan word en die gebrek herstel kan word;

- bekroning ("attribution") dit is die beloning wat die subjek ontvang vir die suksesvolle uitvoering van die kontrak of taak wat aan hom gestel is. Sy beloning is dat hy die objek vir homself verkry. Iemand anders as die subjek kan egter ook die ontvanger wees, soos byvoorbeeld die gewonde man in bogenoemde gelykenis.

Greimas gebruik dikwels die term "toets" vir hierdie sintagma en die handelinge wat daardeur beskryf word. Hy onderskei drie toetse waaraan die held onderwerp word, naamlik:

- kwalifiserende toets: die held word hiermee gekwalifiseer as die subjek van die taak wat onderneem moet word en ontvang hulp van die helper;

- hooftoets ("main principal test"): so genoem omdat dit te make het met die beslissende gebeure met betrekking tot die opdrag van die subjek;

- bekronings-/verheerlikingstoets ("glorifying test"): die subjek ontvang erkenning van die sosiale gemeenskap waarin hy hom bevind.

\subsection{Die sekwensie ("sequence")}

Die volgende stap in die analise van 'n vertelling is die identifisering van die sekwensies in die vertelling. Verskillende sintagmas kombineer om 'n sekwensie te vorm. In die vertelgrammatika is die sekwensie 'n sintaktiese makro-eenheid, 'n onveranderlike wat gedefinieer word deur die relasies tussen die sintagmas. Dit is die relasies van implikasie en vooronderstelling. Daar is twee soorte sekwensies, naamlik die korrelatiewe en die saak- ("topical") sekwensies. Eersgenoemde verteenwoordig onderskeidelik die situasie aan die begin en aan die einde van die vertelling en laasgenoemde is die sekwensie(s) wat tussen die twee afspeel. Die sintagmatiese struktuur van die sekwensies sien dus soos volg daaruit: aanvanklik-korrelatiewe sekwensie/saaksekwensie(s)/eind-korrelatiewe sekwensie.

Die aanvanklik-korrelatiewe sekwensie behels die volgende (kyk Howard 1981: 128 v):

(i) dit dui die rede aan vir die vertelling deur die gebreksituasie te beskryf;

(ii) aan die karakters word hulle rolle op die aktante-model toegewys;

(iii) dit vermeld die aanbieding van 'n kontrak of mandaat deur die sender aan die subjek om die objek wat gemis word aan die 
ontvanger te kommunikeer. Word die mandaat aanvaar, gaan die vertelling oor na die saaksekwensie(s). Word dit nie aanvaar nie, moet 'n nuwe mandaat aan 'n ander subjek gegee word.

Die saaksekwensies behels die volgende:

(i) hulle beskryf die handelinge van die subjek om die objek aan die ontvanger te kommunikeer;

(ii) elke nuwe sekwensie beteken 'n nuwe sub-kontrak tussen subjek en verskeie helpers;

(iii) vir elke saaksekwensie is daar' $n$ verskillende aktante-model. So sal 'n helper in 'n sub-kontrak byvoorbeeld die objek wees wat aan die subjek as ontvanger gekommunikeer moet word.

Die eind-korrelatiewe sekwensie behels die volgende:

(i) dit beskryf die uiteinde van die verloop van sake, dit wil sê die herstel van die aanvanklike situasie soos dit teweeggebring is deur die optrede van die subjek, dus die vervulling van die hoofkontrak;

(ii) die aktante-model is hier dieselfde as by die aanvanklike sekwensie, naamlik sender, objek, ontvanger.

Die aanduiding van die begin van 'n nuwe sekwensie word telkens gemerk deur 'n nuwe kontrak wat aangegaan word. 'n Nuwe kontrak veronderstel ook altyd 'n nuwe aktante-model en 'n nuwe stel relasies tussen die karakters.

\section{GRAFIESE VOORSTELLING VAN ELEMENTE VAN VERTELLING}

Hoewel dit geensins al die elemente van of verbande in 'n vertelling volledig skets nie, sou ons die hoofelemente en verbande soos volg grafies kon voorstel:

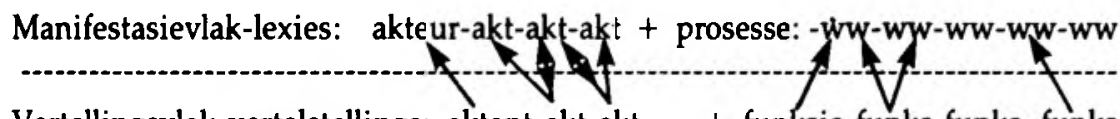

Vertellingsvlak-vertelstellings: aktant-akt-akt + funksie-funks-funks -funks

Diepvlak - Opposisionele relasies:

Sintagmatiese ordening

$\rightarrow$ Sintagmas: Kontraktuele $\rightarrow$

skeiding $\rightarrow$ performatief
- konfrontasie
- dominasie
- bekroning

$\rightarrow$ sekwensies: eerste korrelatiewe sekwensie -

saaksekwensie(s) - tweede korrelatiewe sekwensie. 


\section{VOORBEELDE}

Sleutel tot simbole:

$\mathrm{K}=$ kwalifikasie

$\mathrm{KtS}=$ kontraktuele sintagma

DS = skeidingsintagma

PS 1 = performatiewe sintagma - konfrontasie

PS 2 = performatiewe sintagma - dominasie

PS 3 = performatiewe sintagma - bekroning

$H=$ baken die verskillende sintagmas af

$(\vdash)$ = dui aan dat die betrokke sintagma by implikasie aanwesig is.

\subsection{Die verlore seun (Lk 15:11 vv, gedeeltelik)}

Lex. 1 , vs $11^{\text {b}}$ : Daar was 'n man wat twee seuns gehad het.

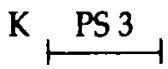

K hierbo dui die kwalifikasie aan dat die man twee seuns gehad het.

PS 3 as performatiewe sintagma van die derde tipe dui aan dat die man as ' $t$ ware bekroon is met drie seuns

Lex. 2, vs 12: Die jongste sê vir sy vader.

DS
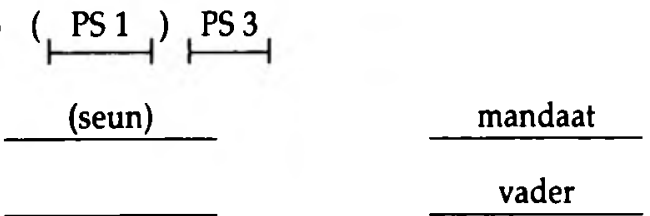

vader

DS as skeidingsintagma dui aankoms aan, die seun kom by sy pa en sê vir hom iets. (PS 1) dui aan dat konfrontasie geimpliseer word en PS 3 dui aan dat wat gesê is, by die vader tuisgekom het, hy is dus daardeur "bekroon" as ontvanger van die sê-ding.

Lex. 3, vs $12^{\text {b }}$ : Pa gee my die deel van die besittings wat my toekom.

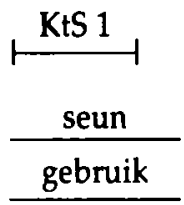

\begin{tabular}{c} 
erfdeel \\
\hline vader \\
\hline
\end{tabular}

seun

KtS 1 dui aan dat met wat die seun sê, hy 'n mandaat aan die vader gee. Dit is ook die eerste kontrak of mandaat in die verhaal, daarom met 1 gemerk. 
Lex. 4, vs $12^{\mathrm{c}}$ : Hy het toe die goed onder hulle verdeel.

$\frac{\frac{\text { KtS 1 }}{\text { seun }}}{\text { gebruik }} \mid \frac{\text { PS 2 }}{\frac{\text { deel van goed }}{\text { vader }}}$

seun

KtS 1 dui aan dat dit nog om dieselfde mandaat as hierbo gaan, PS 2 dat dominasie van die pa deur die seun plaasvind en daarom realiseer PS 3 ook, die seun word "bekroon" deurdat hy ontvang wat hy gevra het.

vs $12^{\text {: }}$ : (tussen hulle)

PS 2 PS 3

\begin{tabular}{c} 
die goed \\
vader \\
\hline
\end{tabular}

twee seuns

PS 2 \& 3 neem weer die feit van dominasie en bekroning op, maar in hierdie geval om daaraan uitdrukking te gee dat albei die seuns hulle erfdeel ontvang, al sou die ander seun eers later werklik erf.

Lex. 5, vs 13: Nie lank daarna nie het die jongste seun alles tot geld gemaak en van die ouerhuis af na 'n ver land vertrek. Daar het hy sy geld verkwis deur losbandig te lewe.

$\stackrel{\text { vs 13: }}{\longmapsto}$ PS 3

vader $\quad \frac{\text { erfdeel }}{\text { seun }}$

seun

PS 3 dui hier aan dat die geld waarvoor die erfdeel verkoop is, deur die seun in ontvangs geneem is.

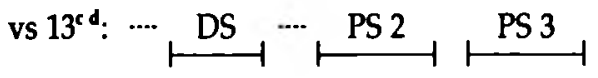

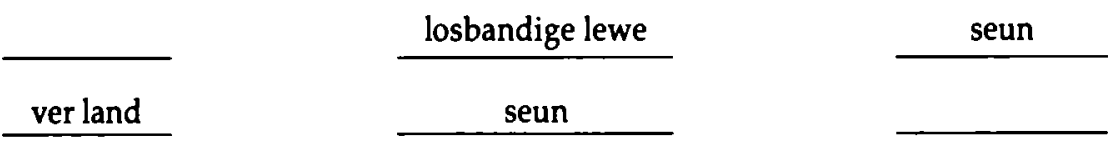

DS: die seun vertrek. PS 2: die seun domineer ten opsigte van die losbandige lewe en hy word bekroon deur die genietinge van hierdie lewe, PS 3

4.2 Die barmhartige Samaritaan (Lk 10:30-35)

$\cap=$ gebrek ("lack")

$U=$ gebrek herstel ("lack liquidated") 
Lexie 1: vs $30^{b}$ : Toe' $n$ man eenmaal op pad was van Jerusalem af na Jerigo toe, het rowers hom aangeval.

vs $30^{b}$ : $\quad$ man $\cup$ gesondheid
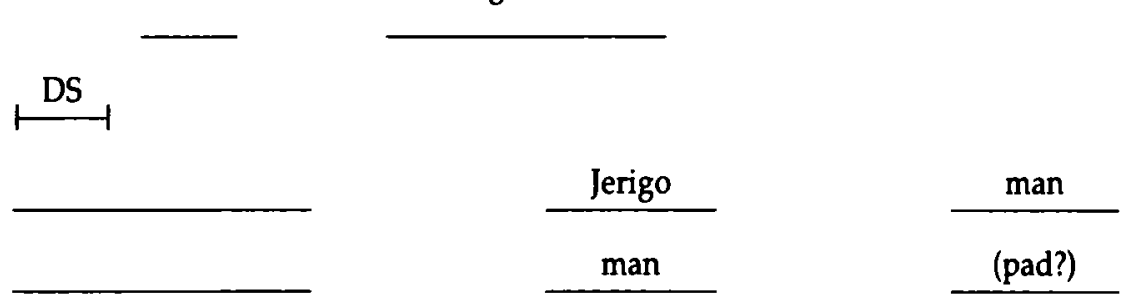

vs 30 : ... het rowers hom aangeval.

$($ ( DS $) \stackrel{\mathrm{Kt} \mathrm{S} 1}{\text { PS } 1}$

rowers

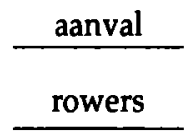

slegte gesindheid/pad

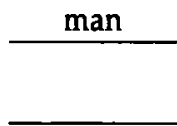

man $\cap$ gesondheid

Lexie 2: vs $30^{\text {de: }}$ Hulle het hom kaal uitgetrek en hom geslaan dat hy halfdood bly lê en toe padgegee.

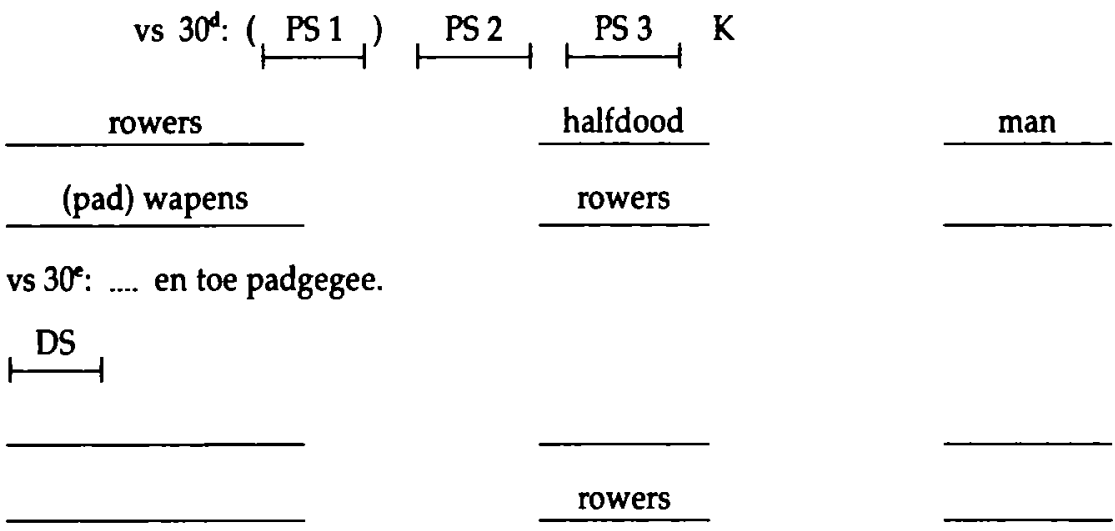

Lexie 3: vs 31. Dit gebeur toe dat daar 'n priester met daardie pad langs kom, en toe hy hom sien, gaan hy verlangs verby.
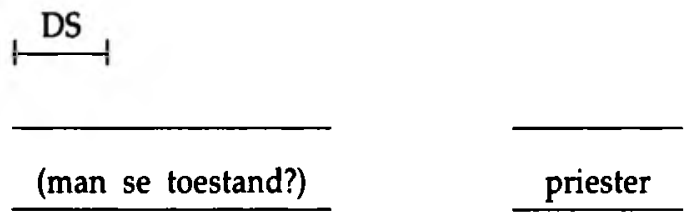

mandaat nie aanvaar nie 
Lexie 4: vs 32 Net so het daar ook 'n Leviet by die plek gekom, en toe hy hom sien, gaan hy ook verlangs verby.

DS

(man se toestand?)

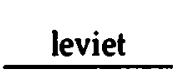

mandaat nie aanvaar nie

Lexie 5: vs 33 Maar 'n Samaritaan wat op reis was, het op hom afgekom, en toe hy hom sien, het hy hom innig jammer gekry.

$\stackrel{\mathrm{DS}}{\mathrm{KtS} 1}$

(God?)

meegevoel

man

(man se toestand?)

Samaritaan

Lexie 6: vs $34^{\text {b }}$ Hy het na hom toe gegaan, sy wonde met olie en wyn behandel en hulle verbind.

$(\stackrel{\text { KtS } 1}{\longmapsto}) \stackrel{\text { PS } 1}{\longmapsto} \stackrel{\text { PS } 2}{\longmapsto} \stackrel{\text { PS } 3}{\longmapsto}$

gesondheid

man

kundigheid, olie, wyn

Samaritaan

rowers en wonde

Lexie 7: vs $34^{\text {cd e }}$ Toe het hy hom op sy rydier gehelp en hom na' $n$ herberg toe geneem en hom daar verder versorg.

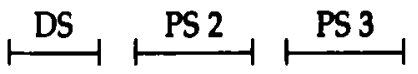

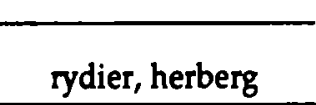

versorging

Samaritaan man

rowers en wonde

Lexie 8: vs 35: Die volgende dag haal hy twee geldstukke uit en gee dit aan die eienaar van die herberg en sê: "Sorg vir hom en as jy meer onkoste met hom het, sal ek jou betaal wanneer ek hierlangs terugkom".

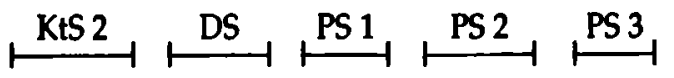

Samaritaan

herberg, geldstukke versorging

herbergier

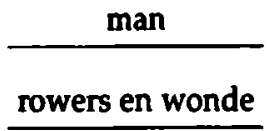

rowers en wonde 


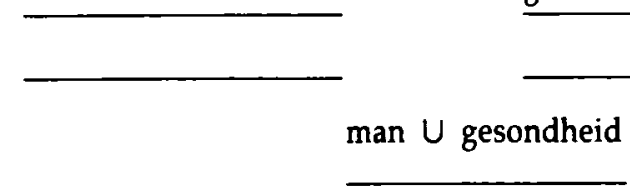

Gebrek herstel

\section{EVALUASIE}

\section{1}

Wanneer die resultate van die verskillende interpretasiemodelle of -teorieë met mekaar vergelyk word, word dit gou duidelik dat daar ' $n$ direkte verband bestaan tussen die bepaalde model wat op ' $n$ teks van toepassing gemaak word en die betekenis wat deur so ' $n$ analise verkry word. Die wat van die betekenis van 'n teks is dus tot op groot hoogte afhanklik van die hoe waarop daardie betekenis bepaal word. Dieselfde geld vir die model van Greimas. Ook hierdie model het 'n kondisionerende uitwerking op die vasstelling van die wat van betekenis. Gevolglik belig ook nie hierdie model al die fasette van die betekenis wat daar in 'n teks opgesluit lê nie.

Die rede hiervoor kan basies teruggevoer word na die geweldige prominensie wat verleen word aan die betekenis wat sogenaamd latent reeds in die dieptestruktuur aanwesig is en waardeur die betekenis op die vertellingsoppervlak geprekondisioneer word. As winspunt van hierdie en verwante strukturale benaderings moet sonder twyfel aangemerk word dat dit ons attent gemaak het op die relasionele betekenis wat daar in binêre opposisies geleë is. Dit is egter ' $n$ vraag of ons moet aanvaar dat hierdie struktuur van betekenis homself so op die voorgrond dring dat die skepper van ' $n$ teks dit in werklikheid onbewustelik op die vertellingsoppervlak orden. Dit laat ' $n$ outeur of verteller as skepper van die teks as ' $t$ ware geheel en al op die agtergrond tree en die struktuur ' $n$ oorweldigende plek inneem. Dit is soos Wittig (1977: 82) dit stel: "The structuralist critic ... virtually ignores the individual creator of the work, arguing (or assuming without argument) that the work is the product of preperceptual structures which operate in the creator's mind at an unconscious level, rather than at a consciously artistic level." Wat vir die outeur geld, geld aan die ander kant ook vir die leser. Hy word in werklikheid nie toegelaat om bewustelik te interpreteer nie. "He (die strukturalis) also assumes without apparently recognizing the assumption) that the audience ... is conditioned to receive and decode 
the message at this unconscious level ..." (Wittig 1977: 82). So 'n benadering laat $\mathrm{min}$ of geen ruimte vir die feit dat die leser of hoorder ' $\mathrm{n}$ faktor is by die vasstelling van betekenis. Vanuit sy verwysingsraamwerk skep hy self ook betekenis vanuit die teks.

Waar alles so opgaan in algemene waarhede dat daar op die vlak van die vertelling eintlik niks gebeur nie, word die boodskap van'n vertelling tot niks meer nie as 'n byproduk van 'n kode wat as baie belangriker as die boodskap geag word. Dit is ' $n$ ernstige vraag of aanvaar kan word dat dit van alle tekste kan geld, en bepaald ook sekere Bybeltekste. Word die kode nie eerder voorveronderstel deur die besonderheid van die boodskap nie? (Kyk Thiselton 1978: 334.)

\section{2}

'n Verdere konsekwensie van hierdie strukturale benadering tot betekenis is dat daar hiervolgens slegs een betekenis in ' $n$ teks aanwesig kan wees, gegenereer deur die een struktuur. Ten opsigte van byvoorbeeld ' $n$ gelykenis word daar dan ook aanvaar dat daar slegs een "regte" betekenis kan wees. Deur so 'n benadering word die moontlikheid geïgnoreer dat tekste meervoudige betekenis kan genereer. Afhangende van hoe bepaald of onbepaald 'n saak in 'n teks tot uitdrukking gebring word, kan die feit nie ontken word nie dat die meerderheid tekste hulle vir meerdere interpretasie leen en dus meervoudige betekenis kan genereer. In hierdie verband moet Wittig (1977: 95) gelyk gegee word wanneer sy byvoorbeeld ten opsigte van die gelykenisse as vertellings sê dat die "ware betekenis" daarvan nie in die struktuur van die teks geleë is nie, maar in die "strukturering" ("structuring") van die teks, "not in die created product but in the process of creation and perception".

\section{3}

Hoewel die teksimmanente werkwyse van strukturalisme algemene instemming behoort te geniet, kan ons ons nie daarmee vereenselwig dat min of geen aandag aan historiese vrae in verband met tekste gegee word nie. "De autonomie van de tekst heft de noodzaak van historische kennis bij de beoefening van de uitlegging ... niet op. Deze blijft altijd een vooronderstelling en een voorwaarde die selfs bij een synchronische lezing van de geschriften uit de verleden de lezer een referentiekader moet geven die hem in staat stelt de tekst syn-chronisch te kunnen lezen" (Vorster 1982: 15; vgl ook Thiselton 1978: 334). So 'n positivistiese benadering tot die outonomie van ' $n$ teks kan maklik daartoe lei dat 'n teks ge-ontkontekstualiseer word en dat dit op sy beurt weer tot 'n nuwe vorm van funda- 
mentalisme aanleiding gee. Dit is ook 'n ernstige vraag of alle betekenis so universeel, gegewe en tydloos is as wat deur strukturalisme voorgegee word.

\section{4}

Verskeie kritici is dit eens dat die strukturale metodes gebruik maak van 'n begripsapparaat en terme wat vir die oningewyde literêre analitikus of eksegeet betreklik onverstaanbaar is. Die indruk wat die oningewyde dus $\mathrm{kry}$, is dat hy eers tot die bykans esoteriese kring van strukturaliste moet behoort alvorens hy in staat sal wees om enigsins te begryp waarom dit in hierdie metodes gaan. Hier is die spreekwoord dat onbekend onbemind maak, dus in 'n hoë mate van toepassing. Aan die ander kant moet egter gewaarsku word dat onbekendheid met hierdie metodes geen verskoning mag wees om hierdie metodes sonder meer te verwerp, en daardeur blind te bly vir die bruikbare en belangrike insigte wat tog daardeur na vore gebring is nie.

\section{5}

Ten slotte moet daarteen gewaarsku word dat daar nie 'n blote beheptheid met struktuur(e) mag ontwikkel nie. Indien dit gebeur, sit ons met nog 'n vorm van positivisme en met 'n suiwer meganiese vorm van formalisme opgesaal. Soos Vorster (1982: 151) dit stel, kan die gevolg uiteindelik wees "een analyse van de structuren om de structuren zelf".

\section{LITERATUURVERWYSINGS}

Blanché, R 1966. Structures intellectueles. Paris: Vrin.

Calloud, J 1976. Structural analysis of narrative. (Translated by D Patte). Philadelphia: Fortress.

Galland, C 1976. An introduction to the method of AJ Greimas, in AM Johnson (ed). The New Testament and structuralism. Pittsburgh: Pickwick, 1-26.

Grosse, UG 1977. Current trends in French narrative research. Linguistica Biblica 40, $21-54$.

Güttgemanns, E 1976. Introductory remarks concerning the structural study of narrative. Semeia 6, 23-125.

Kovacs, BW 1978. Philosophical foundations for structuralism. Semeia 10, 85-105.

McKnight, EV 1978. Meaning in texts. The historical shaping of a narrative hermeneutics. Philadelphia: Fortress.

Patte, D 1976. What is structural exegesis? Philadelphia: Fortress.

Patte, D \& A Patte 1978. Structural exegesis: from theory to practice. Philadelphia: Fortress.

Propp, V 1968. The morphology of the folktale. 2nd Edition. (Translated by L Scott). Austin: University of Texas Press.

Propp, V 1968. Structure and history in the study of the fairy tale. Semeia 10, 57-83. 
Spivey, RA 1974. Structuralism and biblical studies: the uninvited quest. Interpretation 28, 133-45.

Thiselton, A 1978. Structuralism and Biblical studies: method or ideology? Expository Times 89, 329-35.

Vorster, WS. 1982. De structuuranalyse, in AFJ Klijn (red). Inleiding tot de studie van het Nieuwe Testament. Kampen: Kok, 139-52.

Wittig, S 1975. The historical development of structuralism. Soundings. Journal of interdisciplinary studies. 58, 145-66.

Wittig, S 1977. A theory of multiple meanings. Semeia 9, 75-103. 